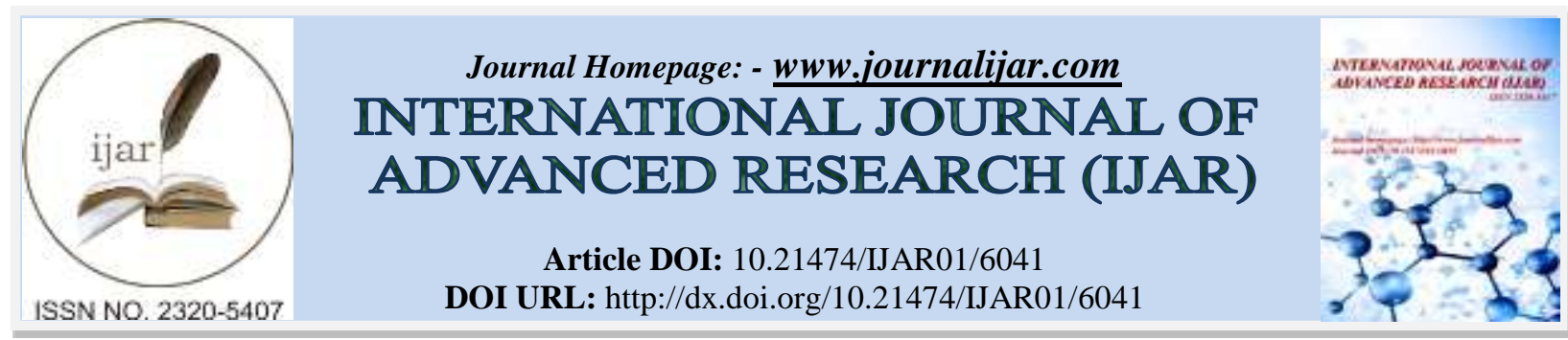

RESEARCH ARTICLE

\title{
RETURN ON INVESTMENT OF PUBLIC SPENDING IN TOURISM POLICY AND INTERNATIONAL TOURISM GROWTH: A COMPARATIVE ANALYSIS BETWEEN COUNTRIES.
}

\author{
Karen Gardenia Ramos Higuera.
}

Facultad de Turismo y Mercadotecnia, Universidad Autónoma de Baja California.

\section{Manuscript Info}

Manuscript History

Received: 12 October 2017

Final Accepted: 14 November 2017

Published: December 2017

\section{Abstract}

The purpose of this study is to examine the relationship between the international tourism growth and public funding invested in the tourism policy by United States, Australia and Mexico. The research method is quantitative, based on country level data; an econometric statistical analysis was carried out, using simple linear regressions. This study found that the public investment in the tourism policy is strongly statistically related to (1) international tourist expenditure generated and (2) the international tourist arrivals visiting the countries.

Copy Right, IJAR, 2017, All rights reserved.

\section{Introduction:-}

According to the World Tourism Organization (WTO, 2017), international tourism includes all displacements that do not convert the traveler into a resident and that are outside their country of residence and who carry out activities as part of their tourist trips. It is recommended that visitor be classified on the basis of their country of residence for measurement purposes. The country of residence or usual environment of an individual, a key concept in tourism, is defined as the geographical area within which an individual carries out his/her regular life routines.

The WTO Ranking is divided into two categories quantifying 1) International tourists' arrivals and 2) International tourists' expenditure. From 2005 to 2014 the United States has remained in the first place in the International tourists' expenditure category. For the arrivals category, U.S has occupied the first to the third place in this same period of time (WTO, 2007, 2009, 2011, 2013 and 2015).

The case of Australia is remarkable, despite having atypical geographical and commercial conditions; it has managed to stay within the top 10 countries with highest International tourists' expenditure since 2005 until 2012. In 2013 and 2014 the performance of the indicators decreased, the country did not positioned within the first ten places. However, in the ranking of international arrivals in this analyzed period, Australia did not manage to be included in the top ten positions of this ranking (WTO, 2007, 2009, 2011, 2013 and 2015).

Unlike Australia, Mexico has not managed to position itself among the top 10 countries for International tourist's expenditure. However, from 2005 to 2006, Mexico obtained the eighth place in the international tourists' arrival category. From 2007 to 2010 there was a decrease in the number of arrival and the country dropped down to the 10 position. In 2011 and 2012 it was not placed in any of the 10 positions of the leading countries in this category, achieving again the tenth position in the years 2013 and 2014 (WTO, 2007, 2009, 2011, 2013 and 2015). 
In Mexico, the Secretariat of Federal Tourism (SECTUR, 2013) establishes that the challenge of the tourism sector is to increase competitiveness, for this purpose deliberate public actions are required, starting from an assessment of the tourism sector current state, throughout this analysis, design and implement an articulated tourism policy with clear objectives. In this sense, it is necessary to evaluate the efficiency of the tourism public policies and allocation of public budget spent through the return on investment (ROI) and the accomplishment of increasing visitors to the country.

It is necessary to investigate is whether tourist are actually traveling to, and spending money in the countries that have the largest budgets in the tourism policy, and understanding if the public investment is related to tourist arrivals and the generation of tourism revenues at country level in these particular destinations (Fall, 200).

In sum, the relationship between public investment in tourism policy and the growth of international tourism is currently unknown. For this reason, it is essential to carry out an analysis of public spending on tourism policies, to determine its degree of influence on generation of international tourist arrival and expenditures in these countries.

\section{Literature Review:-}

Shaw and Williams (2002) affirmed that tourist arrivals and their consumption decisions is the output of a complex set of relationships between tourism businesses and the public sector. Such mix can generate positive economic outcomes. To understand if this relationship is attracting more economic contribution, Rosentraub and Joo (2009) argued that contextual analyses shall be carry out to identify the ROI of public spending and its outcomes must be taken in account for the economic and tourism policies design.

Pratt, McCabe, Cortes-Jimenez, and Blake (2010) sustained that there are a number of different ways to measure the success of tourism policy and its marketing efforts, including conversion rates, different measures of costeffectiveness, cost-benefit and return on investment statistics.

Cost-benefits and cost-effectiveness analyses provide a frame of reference relating costs to results, both asses work toward the accomplishment of the objectives of a program. The main difference line in the terms effects are expressed within public policy (program). In a cost-benefit analysis the outcomes are express in monetary and, the cost-effectiveness assess the outcomes in substantive terms (Fall, 2002).

In order to calculate de cost-benefit it is necessary to estimate a revenue-to-expenditures ratio, also named monetary value or return on investment (ROI), by dividing each revenue generated from the efforts of the programs (benefits) between the overall public budget spent to carry out the public tourism policies (programs costs) (Fall, 2002) (Barnow \& Trutko, 2015). The incremental expenditure brought to the destination is a direct result of the number of visitors and their expenditures attributed to the marketing campaign and public efforts. (Pratt, McCabe, CortesJimenez, and Blake, 2010).

This methodology was used to estimate number of tourist, visitor expenditures, and hence ROI across 18 different campaigns in the United Kingdom. The correlation analysis identified that the costs of the policy and marketing campaigns are positively related to return on investment, implying that the more government investment on the tourism policy and marketing, the higher the return on investment (Pratt, et. al, 2010).

In addition, the efficiency indicators have to be common measures and established for each specific program, and these indicators should include participant, outcome, and cost data that are currently collected or that could potentially be collected in the future and with the same periodicity (Barnow \& Trutko, 2015).

In the same vein, it is possible to measure tourist expenditure through tourism satellite accounts (TSA) or some quantification from WTO can be used to calculate the increase in economic contribution for each origin market. Public investment for marketing has been the independent variable most studied for its impact on tourism arrivals and expenditure. Those few studies that have been undertaken indicate that public investment in marketing has a positive, but relatively small, effect on international tourism demand. Measures of the ROI can inform to the public organizations about effective allocation of the resources and the tourism growth (Dwyer, et.al, 2013).

It is common that researchers use the budget of national tourism offices as a proxy for marketing expenditure or the tourism policy cost. These data could have limitations, because it is only taken into account the public budget 
invested in the tourism policy. Due to, in some countries the private sector has an active participation in the funding of the marketing efforts designed in the tourism policy. While this marketing effort is supported by investment from private operators, data limitations have compelled researchers to exclude private sector marketing investment (Dwyer, et.al 2013).

Regarding to this point, the private sector has a strong participation in the funding of the public tourism policy. In the United States and Australia, in 2009, the intention of the Tourism Promotion Act (TPA) arises, with the purpose of increasing international tourist arrivals to the United States (OECD, 2012). This Act was signed in March 2010, establishing the creation of a public-private partnership which is called the Corporation for Travel Promotion (CTP), which now operates as USA Brand. The Department of Commerce must work with the private sector to promote international travel to the United States (Department of Commerce of the United States, 2001 and Platzer, 2014).

The Corporation is non-profit and its main function is to communicate the international visitor entry policies to the United States, in this way it seeks to encourage the inflow of international tourism and different types of tourism. The CTP had a budget of \$ 100 million US dollars until the fiscal year 2015 (Congress of the United States, 2009). Budget was obtained from a charge or tax by meeting the requirement of a mandatory form for travelers from visafree countries, as part of the Department of Homeland Security's procedure for the Electronic System for Travel Authorization (ESTA). In the first year, the CPT was financed from a contribution of up to \$ 10 million dollars. In the second year, the contribution of the federation was up to $\$ 100$ million with a counterpart of $50 \%$ in the tourism industry ( $80 \%$ can be in kind, $20 \%$ must be in cash). In the third, fourth and fifth year, the contribution was raised up to $\$ 100$ million dollars with the condition of gathering $100 \%$ by the suppliers in the tourism sector (Committee on Commerce, Science, and Transportation, 2009).

It is important to point out that with the TPA, the Office of Travel and Tourism Industry (OTTI) and USA Brand were encouraged to improve research within the sector. This Law required the expansion of research activities, including access to official data and travel surveys for visitors from the Mexican border, as well as the improvement of the International Travelers Survey and the estimates of International tourists' payment receipts, among others (OECD, 2012 and the Committee on Commerce, Science, and Transportation, 2009). So in the following years the quantification of tourist arrivals and their average expenditure was improved.

In Australia, the Tourism Australia (TA) is the government agency responsible for the international tourism promotion and commercialization, as well as, the research and forecasts of the sector. Within the promotion and marketing campaigns, Tourism Australia implements cooperative associations with the private sector aiming to consolidate the country's brand. These efforts are known as public-private marketing associations to fund the advertising campaigns. The agency partners with media, journalists, travel agencies and other tourism service providers to finance campaigns, either in kind or in cash (Australian Government, 2008).

In 2010, the promotional campaign "There is nothing like Australia" was launched for the international market. The association with the industry was a fundamental part for the financing and implementation of the promotion campaigns, as well as the cooperation from different government institutions (OECD, 2014). These partnerships demonstrate the flexibility of the campaign and allowed Tourism Australia to significantly extend its international reach (Tourism Australia, 2011). The associations were achieved through Memoranda of Understanding and Local Agreements, creating a total of 14 cooperative marketing alliances with airlines from 23 regions worth more than \$ 10 million dollars (Tourism Australia, 2011).

The Secretariat of Tourism (SECTUR) is the federal agency responsible for conducting and consolidating national tourism development, through the activities of planning, offer development, operation of tourism services and promotion support. It has two sectorized entities, the National Fund for Tourism Promotion (FONATUR by its acronyms in Spanish) and the Tourism Promotion Council of Mexico (CPTM by its acronyms in Spanish) (SECTUR, 2011).

In 1999, the executive order was published to reform and add various provisions of the General Tourism Law, which establishes that the Tourism Secretariat, in the execution of its promotion duties for national and international tourism, will be assisted by the Majority State Participation Company called Consejo de Promoción Turística de México, S.A. de C.V., who aims to plan, design and coordinate marketing policies and strategies in collaboration 
with the Secretariat of Tourism. The CPTM was created and stared up with the participation of the Federal Government, through SECTUR and FONATUR (CPTM, 2014).

In this sense, unlike the United States and Australia, in Mexico the public-private partnership scheme is not used to finance the implementation of tourism policy instruments. That is, the cost of operating these entities and the national and international promotion campaigns are fully covered with public investment

\section{Methodology:-}

Objective:

To analyze the relationship between public investment in tourism policy and the International Tourism growth in the United States, Australia and Mexico.

\section{Hypothesis: -}

H0: There is no statistically significant relationship between public investment on tourism policy and the international tourism growth in the selected countries.

$\mathrm{H} 1$ : There is a statistically significant relationship between public investment on tourism policy and the international tourism growth in the selected countries.

\section{Method: -}

The research was carried out under a quantitative approach. A statistical analysis was carried out to determine the relationship between the variables of public fund invested in tourism policy instruments and the international tourism growth.

To evaluate the tourism policy of the selected countries, the cost-benefit analysis was done to measure ROI of the public spending in the tourism policy (Pratt, et al., 2010) ( Fall, 2010) (Barnow \& Trutko, 2015)..From this perspective, and with the purpose of evaluating the results of the public budget exercised in one year with respect to the following year, public budget spent in tourism policies by the selected countries was included from the period 2004 to 2013, and the quantification of international tourism indicators were from a year after 2005 to 2014 .

In order to determine the relation between public budget invested in tourism policy and the growth of the segment, the indicators of the UNWTO World Tourism Barometer were used: 1) international tourist arrivals and 2) international tourist expenditure generated in the selected countries.

\section{Analysis and statistical tools: -}

Simple linear regression analysis was carried out based on country level data using the variables of: 1) Public fund invested in the tourism policy and 2) international tourism growth. This last variable is measured by two indicators: International tourists' arrivals and international tourist expenditure.

It was taking into account only the public investment because Mexico did not have private participation in the public policy expenditure. The historical series of public spending and international tourist expenditure of the different countries were deflated to the base year 2015 by means of the Consumer Price Index (CPI) method. This index is based on the percentage of inflation that was presented annually for 10 years in each of the countries studied. Subsequently, to standardize public investments, the currencies of the different countries were converted to US dollars at the average exchange rate of 2015. The international tourist expenditure data are quantified by the UNWTO in US dollars, for this reason the series data was deflated by the CPI method, using only the inflation presented in the United States.

\section{Results:-} United States

\begin{tabular}{|c|c|c|c|c|}
\hline \multicolumn{6}{|c|}{ Table 1. United States international tourism growth } \\
\hline YEAR & $\begin{array}{c}\text { Public Investment } \\
\text { (Millions of dollars) } \\
\text { Current prices 2015 }\end{array}$ & $\begin{array}{c}\text { International Tourist } \\
\text { Arrivals (Millions) }\end{array}$ & $\begin{array}{c}\text { International Tourist } \\
\text { Expenditure (Billions } \\
\text { of dollars) } \\
\text { Constant data }\end{array}$ & $\begin{array}{c}\text { International Tourist } \\
\text { Expenditure (Billions } \\
\text { of dollars) } \\
\text { Current prices } \\
\end{array}$ \\
& & 2015 \\
\hline
\end{tabular}




\begin{tabular}{|c|c|c|c|c|}
\hline 2005 & $\$ 9.75$ & 49.2 & 81.8 & 103.5 \\
\hline 2006 & $\$ 14.42$ & 51.1 & 85.7 & 104.7 \\
\hline 2007 & $\$ 6.72$ & 56.0 & 96.7 & 114.4 \\
\hline 2008 & $\$ 6.62$ & 57.9 & 110.0 & 126.5 \\
\hline 2009 & $\$ 2.18$ & 54.9 & 94.2 & 104.2 \\
\hline 2010 & $\$ 2.54$ & 60.1 & 103.5 & 114.5 \\
\hline 2011 & $\$ 2.10$ & 62.7 & 115.6 & 125.9 \\
\hline 2012 & $\$ 13.06$ & 66.7 & 161.6 & 170.3 \\
\hline 2013 & $\$ 107.60$ & 70.0 & 177.5 & 183.1 \\
\hline 2014 & $\$ 105.14$ & 75.1 & 192.3 & 195.4 \\
\hline \multicolumn{5}{|c|}{$\begin{array}{l}\text { Source: National Travel and Tourism Office (2016). International Trade Administration }(2005,2006,2007,2008) \text { y, } \\
\text { BRAND U.SA. (2011, 2012,2013) OECD (2010, 2012). Committee on Commerce, Science, and Transportation } \\
\text { (2007) World Bank (2016), U.S. Department of Treasury (2017) y WTO, (2006, 2008, 2010, 2012, 2014). }\end{array}$} \\
\hline
\end{tabular}

Figure 1: - Linear regression between international tourist arrivals and public investment in the United States

\begin{tabular}{|c|c|c|c|c|}
\hline \multicolumn{5}{|c|}{ Dependent Variable: ARRIVALSUSA } \\
\hline \multicolumn{5}{|c|}{ Method: Least Squares } \\
\hline \multicolumn{5}{|c|}{ Sample: 20042013} \\
\hline \multicolumn{5}{|c|}{ Included observations: 10} \\
\hline Variable & Coefficient & Std. Error & t-Statistic & Prob. \\
\hline $\mathrm{C}$ & 56.34427 & 2.209097 & 25.50556 & 0.0000 \\
\hline INVUSA & 0.149030 & 0.045854 & 3.250111 & 0.0117 \\
\hline R-squared & 0.569040 & \multicolumn{2}{|l|}{ Mean dependent var } & 60.37000 \\
\hline Adjusted R-squared & 0.515170 & \multicolumn{2}{|l|}{ S.D. dependent var } & 8.307299 \\
\hline S.E. of regression & 5.784348 & \multicolumn{2}{|l|}{ Akaike info criterion } & 6.525045 \\
\hline Sum squared resid & 267.6695 & \multicolumn{2}{|l|}{ Schwarz criterion } & 6.585562 \\
\hline Log likelihood & -30.62522 & \multicolumn{2}{|l|}{ Hannan-Quinn criter. } & 6.458658 \\
\hline F-statistic & 10.56322 & \multicolumn{2}{|l|}{ Durbin-Watson stat } & 0.869131 \\
\hline Prob(F-statistic) & 0.011699 & & & \\
\hline
\end{tabular}

Figure 1 shows that the overall significance of the model is (0.0117), the international tourist arrivals (ARRIVALSUSA) have a statistically significant positive relationship with public budget spent on the tourism policy (INVUSA), because the p-value is less than 0.05 ( $\pm 5 \%$ error margin). For this reason, the international tourist arrivals are explained by the public spending on tourism policy. Analyzing the result of the $\mathrm{R}^{2}(0.569040)$, it can be concluded that international tourist arrivals to the United States are explained $57 \%$ by the public investment on the tourism policy.

Figure 2:- Linear regression between international tourist expenditure and public investment in tourism policy in the United States

\begin{tabular}{|c|c|c|c|c|}
\hline \multicolumn{4}{|c|}{ Dependent Variable: EXPUSA } & \\
\hline \multicolumn{4}{|c|}{ Method: Least Squares } & \\
\hline \multicolumn{5}{|l|}{ Sample: 20042013} \\
\hline \multicolumn{5}{|c|}{ Included observations: 10} \\
\hline Variable & Coefficient & Std. Error & t-Statistic & Prob. \\
\hline $\mathrm{C}$ & 115.3863 & 7.757545 & 14.87408 & 0.0000 \\
\hline INVUSA & 0.698318 & 0.161021 & 4.336803 & 0.0025 \\
\hline R-squared & 0.701580 & \multicolumn{2}{|c|}{ Mean dependent var } & 134.2500 \\
\hline Adjusted R-squared & 0.664278 & \multicolumn{2}{|c|}{ S.D. dependent var } & 35.05691 \\
\hline S.E. of regression & 20.31252 & \multicolumn{2}{|c|}{ Akaike info criterion } & 9.037209 \\
\hline Sum squared resid & 3300.789 & \multicolumn{2}{|c|}{ Schwarz criterion } & 9.097726 \\
\hline Log likelihood & -43.18604 & \multicolumn{2}{|c|}{ Hannan-Quinn criter. } & 8.970822 \\
\hline
\end{tabular}




\begin{tabular}{|l|l|l|l|}
\hline F-statistic & 18.80786 & Durbin-Watson stat & 1.625486 \\
\hline Prob(F-statistic) & 0.002489 & & \\
\hline
\end{tabular}

Considering the results obtained in the overall significance of the model $(0.0025)$ observed in Figure 2, the international tourist expenditure variable (EXPUSA) has a statistically significant positive relationship with public budget invested (INVUS) in the tourism policy, because the p-value is less than 0.05 ( $\pm 5 \%$ margin of error). Taking into account the result of the $\mathrm{R}^{2}(0.701580), 70 \%$ of the international tourist expenditures are explained for the public spending on the tourism policy.

Australia:-

Table 2. Australia international tourism growth

\begin{tabular}{|c|c|c|c|c|}
\hline YEAR & $\begin{array}{c}\text { Public Investment } \\
\text { (Millions of dollars) } \\
\text { Current prices 2015 }\end{array}$ & $\begin{array}{c}\text { International } \\
\text { Tourist Arrivals } \\
\text { (Millions) }\end{array}$ & $\begin{array}{c}\text { International Tourist } \\
\text { Expenditure (Billions } \\
\text { of dollars) } \\
\text { Constant data }\end{array}$ & $\begin{array}{c}\text { International Tourist } \\
\text { Expenditure (Billions } \\
\text { of dollars) } \\
\text { Current prices } \\
\mathbf{2 0 1 5}\end{array}$ \\
\hline $\mathbf{2 0 0 5}$ & 139.354 & 5.5 & 16.7 & 21.1 \\
\hline $\mathbf{2 0 0 6}$ & 135.551 & 5.6 & 17.8 & 21.8 \\
\hline $\mathbf{2 0 0 7}$ & 128.123 & 5.7 & 22.3 & 26.4 \\
\hline $\mathbf{2 0 0 8}$ & 125.246 & 5.6 & 24.8 & 28.5 \\
\hline $\mathbf{2 0 0 9}$ & 124.058 & 5.6 & 25.4 & 28.1 \\
\hline $\mathbf{2 0 1 0}$ & 122.167 & 5.8 & 28.6 & 31.6 \\
\hline $\mathbf{2 0 1 1}$ & 107.492 & 5.9 & 31.8 & 33.6 \\
\hline $\mathbf{2 0 1 2}$ & 109.283 & 6.1 & 31.9 & 32.3 \\
\hline $\mathbf{2 0 1 3}$ & 103.158 & 6.4 & 31.3 & 32.4 \\
\hline $\mathbf{2 0 1 4}$ & 101.886 & 6.9 & 31.9 & \\
\hline $\begin{array}{l}\text { Source: Tourism Australia (2005,2006, 2007, 2008, 2009, 2010, 2011, 2012, 2013, 2014), World Bank } \\
\text { (2016), U.S. Department of Treasury (2017) y WTO }(2006,2008,2010,2012,2014,2016) .\end{array}$ \\
\hline
\end{tabular}

Figure 3: - Linear regression between international tourist arrivals and public investment in Australia

\begin{tabular}{|c|c|c|c|c|}
\hline \multicolumn{4}{|c|}{ Dependent Variable: ARRIVAU } & \\
\hline \multicolumn{4}{|c|}{ Method: Least Squares } & \\
\hline \multicolumn{5}{|c|}{ Sample: 20042013} \\
\hline \multicolumn{5}{|c|}{ Included observations: 10} \\
\hline Variable & Coefficient & Std. Error & t-Statistic & Prob. \\
\hline $\mathrm{C}$ & 9.298461 & 0.730047 & 12.73681 & 0.0000 \\
\hline INVAU & $-2.83 \mathrm{E}-05$ & $6.07 \mathrm{E}-06$ & -4.667511 & 0.0016 \\
\hline R-squared & 0.731414 & \multicolumn{2}{|c|}{ Mean dependent var } & 5.910000 \\
\hline Adjusted R-squared & 0.697841 & \multicolumn{2}{|c|}{ S.D. dependent var } & 0.443346 \\
\hline S.E. of regression & 0.243703 & \multicolumn{2}{|c|}{ Akaike info criterion } & 0.191121 \\
\hline Sum squared resid & 0.475128 & \multicolumn{2}{|c|}{ Schwarz criterion } & 0.251638 \\
\hline Log likelihood & 1.044396 & \multicolumn{2}{|c|}{ Hannan-Quinn criter. } & 0.124734 \\
\hline F-statistic & 21.78566 & \multicolumn{2}{|c|}{ Durbin-Watson stat } & 0.971401 \\
\hline Prob(F-statistic) & 0.001608 & & & \\
\hline
\end{tabular}

Figure 3 shows the results obtained in the overall significance of the model $(0.0016)$, the international tourists arrivals variable (ARRIVAU) has significant statistical relationship with public budget invested (INVAU) in the tourism policy, because the $\mathrm{p}$-value is less than 0.05 ( $\pm 5 \%$ error margin).

Since the regression coefficient of the public investment variable (GASTOAU) is negative (-2.8), it was concluded that the existing relationship is inverse, so that by decreasing public spending on tourism policy, the country 
achieved an increase in the international tourists arrivals. Considering the result of the $\mathrm{R}^{2}(0.731414)$, it is affirmed that $73 \%$ of international tourists arrivals to Australia are explained by the public budget spent in the tourism policy. In this sense, the lower the public investment, the greater the number of international tourists traveling to this country.

Figure 4:- Linear regression between international tourist expenditure and public investment in tourism policy in Australia

\begin{tabular}{|c|c|c|c|c|}
\hline \multicolumn{4}{|c|}{ Dependent Variable: EXPAU } & \\
\hline \multicolumn{5}{|c|}{ Method: Least Squares } \\
\hline \multicolumn{5}{|c|}{ Sample: 20042013} \\
\hline \multicolumn{5}{|c|}{ Included observations: 10} \\
\hline Variable & Coefficient & Std. Error & t-Statistic & Prob. \\
\hline $\mathrm{C}$ & 67.83338 & 6.193228 & 10.95283 & 0.0000 \\
\hline INVAU & -0.000324 & $5.15 \mathrm{E}-05$ & -6.299033 & 0.0002 \\
\hline R-squared & 0.832207 & \multicolumn{2}{|c|}{ Mean dependent var } & 29.04000 \\
\hline Adjusted R-squared & 0.811233 & \multicolumn{2}{|c|}{ S.D. dependent var } & 4.758431 \\
\hline S.E. of regression & 2.067411 & \multicolumn{2}{|c|}{ Akaike info criterion } & 4.467328 \\
\hline Sum squared resid & 34.19351 & \multicolumn{2}{|c|}{ Schwarz criterion } & 4.527845 \\
\hline Log likelihood & -20.33664 & \multicolumn{2}{|c|}{ Hannan-Quinn criter. } & 4.400941 \\
\hline F-statistic & 39.67782 & \multicolumn{2}{|c|}{ Durbin-Watson stat } & 0.864601 \\
\hline Prob(F-statistic) & 0.000233 & & & \\
\hline
\end{tabular}

Figure 4 shows the results obtained in the overall significance of the model $(0.0002)$, the international tourists expenditure variable (EXPAU) has significant statistical relationship with public budget invested (INVAU) in the tourism policy, because the $\mathrm{p}$-value is less than 0.05 ( $\pm 5 \%$ error margin).

Since the regression coefficient of the public investment variable (INVAU) is negative (-0.000324), it was concluded that the existing relationship is inverse, so that by decreasing public spending on tourism policy, the country achieved an increase in the international tourists expenditure. Considering the result of the $\mathrm{R}^{2}(0.8322)$, it is affirmed that $83 \%$ of the international tourists expenditure is explained by the public investment made in the tourism policy. In this sense, the lower the public investment, the more amount of international tourism expenditure generated by this country.

\section{Mexico:-}

\begin{tabular}{|c|c|c|c|c|}
\hline \multicolumn{5}{|c|}{ Table 3. Mexico international tourism growth } \\
\hline YEAR & $\begin{array}{c}\text { Public Investment } \\
\text { (Millions of } \\
\text { dollars) } \\
\text { Current prices } \\
\mathbf{2 0 1 5}\end{array}$ & $\begin{array}{c}\text { International } \\
\text { Tourist Arrivals } \\
\text { (Millions) }\end{array}$ & $\begin{array}{c}\text { International Tourist } \\
\text { Expenditure (Billions } \\
\text { of dollars) } \\
\text { Constant data }\end{array}$ & $\begin{array}{c}\text { International } \\
\text { Tourist } \\
\text { Expenditure } \\
\text { (Billions of dollars) } \\
\text { Current prices } \\
\mathbf{2 0 1 5}\end{array}$ \\
\hline $\mathbf{2 0 0 5}$ & 238.75 & 21.9 & 11.8 & 14.93 \\
\hline $\mathbf{2 0 0 6}$ & 241.31 & 21.4 & 12.2 & 14.91 \\
\hline $\mathbf{2 0 0 7}$ & 178.32 & 21.6 & 12.9 & 15.2 \\
\hline $\mathbf{2 0 0 8}$ & 265.30 & 22.6 & 13.3 & 15.3 \\
\hline $\mathbf{2 0 0 9}$ & 400.32 & 22.3 & 11.5 & 12.7 \\
\hline $\mathbf{2 0 1 0}$ & 484.94 & 23.3 & 12.0 & 13.3 \\
\hline $\mathbf{2 0 1 1}$ & 403.76 & 23.4 & 11.9 & 13 \\
\hline $\mathbf{2 0 1 2}$ & 482.72 & 23.4 & 12.7 & 13.4 \\
\hline $\mathbf{2 0 1 3}$ & 529.86 & 24.2 & 13.9 & 16.3 \\
\hline $\mathbf{2 0 1 4}$ & 443.44 & 29.3 & 16.2 & \\
\hline
\end{tabular}


Source: Centro de Estudios de Finanzas Públicas (CEFP, 2013 y 2015) INEGI (2013, 2014). World Bank (2016) U.S. Department of Treasury (2017) y WTO (2006, 2008, 2010, 2012, 2014).

Figure 5:- Linear regression between international tourist arrivals and public investment in Mexico

\begin{tabular}{|c|c|c|c|c|}
\hline \multicolumn{4}{|c|}{ Dependent Variable: ARRIVALSMX } & \\
\hline \multicolumn{4}{|c|}{ Method: Least Squares } & \\
\hline \multicolumn{5}{|c|}{ Sample: 20042013} \\
\hline \multicolumn{5}{|c|}{ Included observations: 10} \\
\hline Variable & Coefficient & Std. Error & t-Statistic & Prob. \\
\hline C & 19.68613 & 2.085381 & 9.440061 & 0.0000 \\
\hline INVMX & 0.009960 & 0.005409 & 1.841205 & 0.1029 \\
\hline R-squared & 0.297632 & \multicolumn{2}{|c|}{ Mean dependent var } & 23.34000 \\
\hline Adjusted R-squared & 0.209836 & \multicolumn{2}{|c|}{ S.D. dependent var } & 2.279474 \\
\hline S.E. of regression & 2.026251 & \multicolumn{2}{|c|}{ Akaike info criterion } & 4.427108 \\
\hline Sum squared resid & 32.84555 & \multicolumn{2}{|c|}{ Schwarz criterion } & 4.487625 \\
\hline Log likelihood & -20.13554 & \multicolumn{2}{|c|}{ Hannan-Quinn criter. } & 4.360721 \\
\hline F-statistic & 3.390036 & \multicolumn{2}{|c|}{ Durbin-Watson stat } & 1.241917 \\
\hline Prob(F-statistic) & 0.102855 & & & \\
\hline
\end{tabular}

Observing the results obtained in the overall significance of the model (0.1028) within figure 5, international tourists arrivals (ARRIVALSMX) have no significant statistical relationship with public budget (INVMX) spent on tourism policy, because the $\mathrm{p}$-value is greater than 0.05 ( $\pm 5 \%$ error margin). For this reason, international tourists' arrivals to the country are not explained by the public spending on the tourism policy.

Figure 6:- Linear regression between international tourist expenditure and public investment in tourism policy in Mexico

\begin{tabular}{|c|c|c|c|c|}
\hline \multicolumn{4}{|c|}{ Dependent Variable: EXPMX } & \\
\hline \multicolumn{4}{|c|}{ Method: Least Squares } & \\
\hline \multicolumn{5}{|c|}{ Sample: 20042013} \\
\hline \multicolumn{5}{|c|}{ Included observations: 10} \\
\hline Variable & Coefficient & Std. Error & t-Statistic & Prob. \\
\hline $\mathrm{C}$ & 15.89075 & 1.181066 & 13.45459 & 0.0000 \\
\hline INVMX & -0.004216 & 0.003064 & -1.376198 & 0.2061 \\
\hline R-squared & 0.191423 & \multicolumn{2}{|c|}{ Mean dependent var } & 14.34400 \\
\hline Adjusted R-squared & 0.090351 & \multicolumn{2}{|c|}{ S.D. dependent var } & 1.203220 \\
\hline S.E. of regression & 1.147577 & \multicolumn{2}{|c|}{ Akaike info criterion } & 3.290040 \\
\hline Sum squared resid & 10.53547 & \multicolumn{2}{|c|}{ Schwarz criterion } & 3.350557 \\
\hline Log likelihood & -14.45020 & \multicolumn{2}{|c|}{ Hannan-Quinn criter. } & 3.223653 \\
\hline F-statistic & 1.893922 & \multicolumn{2}{|c|}{ Durbin-Watson stat } & 0.989722 \\
\hline Prob(F-statistic) & 0.206050 & & & \\
\hline
\end{tabular}

As shown in Figure 6, the overall significance of the model is (0.948532), the international tourism expenditure variable (EXPMX) has no significant statistical relationship with public investment (INVMX) in the Mexican tourism policy, because the p-value is above 0.05 ( $\pm 5 \%$ margin of error). For this reason, the international tourism expenditures are not explained by the public budget invested on the tourism policy.

\section{Discussion and Conclusion:-}

With the results presented above, the hypothesis $\mathrm{H} 0$ was rejected, which proposes that there is no statistically significant relationship between public investment in tourism policy and the growth of international tourism in the selected countries. However, hypothesis H1 suggested that there is a significant relationship between the public investment made in tourism policy and the growth of international tourism in the indicators of: 1) foreign exchange generated by international tourism and 2) international tourist arrivals; It was partially approved, because it was only 
validated in two countries: The United States and Australia, these findings are in accordance with the results of Dwyer, et. al, (2013) and Pratt et. al, (2010)

In the case of the United States, where it was found that there is a positive relationship between the variables, it is due to the fact that in the first years public spending on the public policy instruments in tourism was limited, after the approval of the TPA, public investment was increased as long as a certain percentage of private initiative was obtained (US Department of Commerce, 2001 and Platzer, 2014). However, since 2004, within the international tourist expenditures category, it was already in first place in the ranking, and positioned among the first three places in the international tourist arrivals category. By maintaining the leadership positions in both categories of the ranking, the results showed that the higher public investment, the more growth in this segment. Dwyer, et. al, (2013) and Pratt et al.(2010) assured that there was a low statistical relation between the variables. Nevertheless, in this study it was found that the international tourist arrival and expenditure are explained in $51 \%$ and $70 \%$ for the public investment made in the tourist policy.

In Australia, public investment in tourism policy was gradually reduced and the international tourism growth: international tourist expenditure and arrivals. Throughout the period analyzed, there was a reduction in public spending due to the implementation of public-private partnerships to subsidize the costs of designing and implementation of tourism public policies (Tourism Australia, 2008 and 2011). For this reason, the assessment showed a strong statistically significant inverse relationship between the variables, the lower public investment, greater growth of international tourism in the country. The tourist international arrivals and expenditure are explained in $73 \%$ and $83 \%$ for the public investment on the tourism policy. These results contradict the affirmation of Dwyer, et. al, (2013) and Pratt et al. (2010) that there is a low positive statistical relation between the variables.

In this sense, according to Pratt, et al., (2010), Fall (2010), Barnow \& Trutko (2015) from the cost-benefit analysis, the program costs and benefit are monetary quantified. Based on this perspective, Australia and United States demonstrated efficiency in public investment in different ways. Throughout the period analyzed, compared to the other selected nations, the United States made less average public spending, by means of increasing the private investment and incentive them to participate in the same proportion amount, creating a public-private partnership to carry out the country's promotion, obtaining the greatest growth in the segment, therefore the efficiency of tourism policy can be highlighted. On the other hand, Australia reduced public expenditures and obtained an increase in international tourism, which demonstrates the efficiency of public budget invested on tourism policies.

So it can be argued that there are different ways to achieve the return on public investment, but both countries have in common the creation of public-private partnerships according with the affirmation of Dwyer, et. al, (2013) that in some countries the private sector has an active participation in the funding of the marketing efforts designed in the tourism policy.

Finally, in the case of Mexico, it was shown that there is no statistically significant relationship between public investment and the growth of international tourism. The tourism policy is totally subsidized with public spending and the budget allocation has increased annually (CPTM, 2014, CEFP, 2013 and 2015), totally opposite with the rest of the countries studied.

Thus, compared to the rest of the countries analyzed, Mexican public investment is deficient and proportionally four times more expensive than that of other countries. In fact, from 2005 to 2011 the performance indicators remained at the same level, registering a significant increase until 2014. In other words, despite the annual increase in the budget allocated to tourism policy, there has not been an increase in international tourism proportional to public spending. In this sense, the policy is expensive and did not show any benefit.

In summary, it is concluded that public investment has a strong relationship with the international tourism growth. The countries that demonstrated efficiency in public spending are those that implemented instruments with the public-private partnership scheme, which implies less public investment with the planning and implementation of public policies for the tourism sector subsidized by both sectors. With this, the return on public investment is greater and encourages the growth of the international tourism segment. 


\section{References:-}

1. World Bank, (2016). Inflation. World Bank national accounts data, and OECD National Accounts data files. Retrieved

from: http://data.worldbank.org/indicator/NY.GDP.DEFL.KD.ZG?locations=AU\&year_high_desc=false

2. Barnow, S. \& Trutko, J. (2015) The Value of Efficiency Measures: Lessons from Workforce Development Programs, Public Performance \& Management Review, 38:3, 487-513, DOI: 10.1080/15309576.2015.1006466

3. BRAND USA (2011). Brand USA Fiscal Year 2011 Annual Report. Washington: Brand USA

4. BRAND USA (2012). Brand USA Fiscal Year 2012 Annual Report. Washington: Brand USA

5. BRAND USA (2013). Brand USA Fiscal Year 2013 Annual Report. Washington: Brand USA

6. CEFP (2013). Evolución del Gasto Público por Ramos 2000-2012. México Cámara de Diputados

7. CEFP (2015). Índice Nacional de Precios al Consumidor, 1980 - 2015. México Cámara de Diputados

8. Committee on Commerce, Science, and Transportation (2007). Travel Promotion Act of 2007. Washington: Senate

9. CPTM (2014). Manual de Organización del Consejo de Promoción Turística de México, S. A de C. V. México: Consejo de Promoción Turística de México.

10. Dwyer, L., Pham T., Forsyth, P., and Spurr R. (2013). Destination Marketing of Australia: Return on Investment. Journal of Travel Research, Vol. 53(3) pag: 281 -295. SAGE Publications

11. Fall, L., (2002). Examining the Economic Value of Publicity and Promotional Activities Among State Tourism Communication Programs, Journal of Promotion Management, Vol8 (2), 35-46, DOI: 10.1300/J057v08n02_04

12. INEGI (2013). El ingreso y el gasto público en México 2013. Series estadísticas sectoriales. México: Instituto Nacional de Estadística y Geografía.

13. INEGI (2014). El ingreso y el gasto público en México 2014. Series estadísticas sectoriales. México: Instituto Nacional de Estadística y Geografía.

14. ITA (2005). Budget Estimates, Fiscal Year 2005. United States: Department of Commerce of the United States.

15. ITA (2006). Budget Estimates, Fiscal Year 2006. United States: Department of Commerce of the United States.

16. ITA (2007). Budget Estimates, Fiscal Year 2007. United States: Department of Commerce of the United States.

17. ITA (2008). Budget Estimates, Fiscal Year 2008. United States: Department of Commerce of the United States.

18. ITA (2014). Travel and Tourism Advisory Board Members. Washington DC.: International Trade Administration.

19. OECD, (2010). OECD Tourism Trends and Policies 2010. Paris: OECD Publishing.

20. OECD, (2012). OECD Tourism Trends and Policies 2012. Paris: OECD Publishing.

21. WTO, (2006). Tourism Highligts. Madrid: Organización Mundial del Turismo.

22. WTO, (2008). Tourism Highligts. Madrid: Organización Mundial del Turismo.

23. WTO, (2010). Tourism Highligts. Madrid: Organización Mundial del Turismo

24. WTO, (2012). Tourism Highligts. Madrid: Organización Mundial del Turismo

25. WTO, (2014). Tourism Highligts. Madrid: Organización Mundial del Turismo

26. Rosentraub, M. and Joo, M. (2009). Tourism and economic development: Which investments produce gains for regions? Tourism Management Vol. pag: 30 759-770

27. S. Pratt, S McCabe, I Cortes-Jimenez, and A Blake (2010) Measuring the Effectiveness of Destination Marketing Campaigns: Comparative Analysis of Conversion. Journal of Travel Research 49(2) 179 -190. SAGE Publications Studies

28. SECTUR, (2013). Programa Sectorial de Turismo. 2013-2018. México: Autor.

29. Shaw, G., \& Williams, A. M. (2002). Critical issues in tourism: A geographical perspective. Oxford, UK: Blackwell Publisher

30. Tourism Australia, (2005). Anual Report 2004-2005. Australia: Commonwealth of Australia

31. Tourism Australia, (2006). Anual Report 2005-2006. Australia: Commonwealth of Australia

32. Tourism Australia, (2007). Anual Report 2006-2007. Australia: Commonwealth of Australia

33. Tourism Australia, (2008). Anual Report 2007-2008. Australia: Commonwealth of Australia

34. Tourism Australia, (2009). Anual Report 2008-2009. Australia: Commonwealth of Australia

35. Tourism Australia, (2010). Anual Report 2009-2010. Australia: Commonwealth of Australia

36. Tourism Australia, (2011). Anual Report 2010-2011. Australia: Commonwealth of Australia

37. Tourism Australia, (2012). Anual Report 2011-2012. Australia: Commonwealth of Australia

38. Tourism Australia, (2013). Anual Report 2012-2013. Australia: Commonwealth of Australia

39. Tourism Australia, (2014). Anual Report 2013-2014. Australia: Commonwealth of Australia

40. U.S. Department of Treasury (2017). Yearly average currency exchange rates. Retrieved from: https://www.irs.gov/individuals/international-taxpayers/yearly-average-currency-exchange-rates 